\title{
CATEGORIZATION OF IMPACT OF THE SELECTED VARIABLES FOR POTENTIAL BROWNFIELD REGENERATION IN THE CZECH REPUBLIC BY MEANS OF CORRESPONDENCE ANALYSIS
}

\author{
Kamila TURECKOVA ${ }^{1}$, Jan NEVIMA ${ }^{1}$, Jaroslav SKRABAL ${ }^{1}$, Pavel TULEJA ${ }^{1}$
}

DOI: 10.21163/GT_2019.142.11

\begin{abstract}
:
Brownfields are undesirable urbanistic heritage and their occurrence is associated with a number of negative effects, which our society tries to minimize repeatedly, both successfully and unsuccessfully. Especially in the context of the multi-perspective concept of sustainable development, the issue of brownfields is accentuated with the intention to reuse abandoned areas that have lost their original use and regenerate them in a way that enriches not only individual stakeholders but generally the whole society. Although each brownfield is unique within its set of partial characteristics, it is possible to determine by means of mathematical-statistical methods the key patterns that are important for brownfields in terms of their overall nature. The identification of these common patterns across a selected set of brownfields is important for establishing of general recommendations for their potential regeneration. In our paper, we proceeded from the analysis of 460 non-regenerated brownfields located in the Czech Republic, and by means of correspondence analysis we determined which categories most influence the potential brownfield regeneration from the perspective of a two-dimensional (stage) approach. Information on brownfields was taken from the publicly available database of the state-funded company the CzechInvest for 2018 and supplemented by authors with other relevant variables. The analysis of the data revealed factors that may have a major impact in the initial phase of the decision on potential brownfield regeneration, and at the same time factors that do not seem to be substantial for regeneration. The applicability of the results of our analyses creates space for better-targeted brownfield regeneration policies, especially in the area of specifications for calls for brownfield regeneration projects, their financial support, implementation of process innovations, etc.
\end{abstract}

Key-words: Brownfield, Multiple Correspondence, Czech Republic, Factor, Regeneration.

\section{INTRODUCTION}

Remote sensing offers a wide range of satellite imagery which is widely used in Brownfields represent abandoned and unused areas and buildings that are an integral part of urban consequences of human activities that can be transformed into a source of untapped development potential in both regional and national scope. Especially nowadays, when environmental problems are massively emphasized and many activities are assessed from the viewpoint of their acceptability for sustainable development, the urgency to deal with brownfields is repeatedly accentuated. The topic of brownfields thus becomes a relevant transdisciplinary topic for both professional and lay discussions across public and private sectors. Brownfields are currently perceived as a significant, albeit specific, ele-

1 School of Business Administration in Karvina, Silesian University in Opava, Univerzitni Nam.

1934/3, 73340 Karvina, Czech Republic, tureckova@opf.slu.cz,nevima@opf.slu.cz,

skrabal@opf.slu.cz, tuleja@opf.slu.cz. 
ment of spatial development and spatial arrangements of their cultural-natural environments are easily connected to the economic development of regions and simultaneously to the dynamic improvement of quality of life of the population. (Turečková \& Nevima, 2018).

The regeneration of these unused areas requires a systemic approach within the overall development of both national and regional economies and also individual local municipalities. Although each brownfield is specific, it is certainly possible to determine within this set of specific patterns such features that are more similar than others. The aim of our presented research is to find within the selected data of brownfields the influence of individual categories (internal patterns) that are dominant in the process of their potential regeneration. The mathematical-statistical method of correspondence analysis was used for data analysis and a total of five characteristics of 460 brownfields detected in the Czech Republic were examined. From this perspective, we realize that the results of the survey cannot be generalized but are relevant to a similar type of territory in East-Central Europe that has undergone the same major structural and economic changes over the last decade. In general, the methodology of research and interpretations of conclusions can be also used in the analysis of other data.

Identification of regeneration-relevant patterns of brownfields is primarily important for public sector bodies that are dealing with regional development, environmental protection and cohesion policy within the European Union. If we are aware of common patterns for non-regenerated brownfields, we will be able to target both financial and non-financial support and thus move closer to the possibility of their future regeneration.

According to estimations, there are around twelve thousands of sites and areas in the Czech Republic with a total acreage of almost 38 thousand hectares with various level of contamination (CzechInvest, 2008). These sites are relicts of consequences of artificially impeded development of economic restructuring before 1989 and in particular effects of structural changes in Czech economic space that occurred in the following years. Numerous reasons exist why we should be more engaged in the reuse of brownfields. One of the key reasons is the fact that brownfield regeneration contributes to sustainable urban development (Vráblík, 2009; Pakšiová, 2016), prevents land degradation (Turečková et al., 2018), reduces negative effects of suburbanization and urban sprawl (Jackson, 2002) and preserves local, temporal and urbanistic continuity of settlement, societal and environmental structures of given landscape (Turečková \& Chmielová, 2019; Stober et al., 2018).

In the first part of the paper, the issue of brownfields was generally defined together with the relation of brownfields to their neighbourhoods. At the same time, brownfields in the Czech Republic were shortly introduced with a focus on the national brownfield database and its management. More theoretical focus on the research of brownfields can be found in the second chapter of the paper. In the next part, the object of the research was presented and a research proposal together with used methodology was described. The conclusion of the paper summarizes the results of the primary research. In this part, our findings are also discussed and several recommendations are formulated. We also added parts devoted to the practical usage of the results.

\section{THE THEORETICAL FRAMEWORK OF THE STUDY}

No matter what type of research is conducted, the very first item that has to be necessarily done is to embrace the nature of the researched problem. The topic of brownfields has been in general relatively well introduced by plenty of studies and scientific papers. 
Despite all that it was necessary to familiarize ourselves with researches connected to the issue of factors of brownfield regeneration.

Brownfields in regional development might be considered twofold ways. Either as a barrier for regional development or as its source. A fundamental issue is that brownfields are typically bounded with a range of undesirable externalities that tend to even more strengthen the negative perception of brownfields. Brownfields cause minor or major problems, are a limitation for further development of built-up areas and reduce economic development, have a negative impact on the environment, are tied with social and economic impacts on population living in their proximity and have an unfavourable impact on the wider region where they are located (Dennison, 1998). These are the reasons why brownfields should be regenerated. As the authors of plenty of previous studies agree, brownfield regeneration is a site-specific process that is mirrored in the local socio-cultural context and it is a hard task to predict which sites have better chance to be regenerated. It is even more complicated to ensure that particular brownfield regeneration will be successful (Turečková et al., 2018).

A basic requirement of active approach towards brownfields when supporting regional development is to find a new use for abandoned sites and buildings that are instrumental for reduction of pressures on building of new developments on urban greenfields and keeping compactness of present built-up areas. Another supportive argument for reuse of abandoned areas might be found in undesirable effects connected to suburbanization processes and specifically to the problem of urban sprawl. Both mentioned phenomena lead to long term changes of the use of landscape, in other words, they primarily lead to the development of newly built-up areas as well as new technical infrastructure. Within inner parts of cities then remain brownfields, while in the suburban areas, development on greenfields is taking place. Sparse metropolitan development contributes to the increase of commuting distances, to increase of overall time spent by commuting and to the escalation of unjustified requirements for civic amenities and technical infrastructure. We must also mention connections to growing individualisation, loss of social cohesion, weakening of social capital and lack of interest of population on the governance of public matters as we are already aware in cases of socially and culturally homogenous suburban communities (Putman, 2000; Oliver 2001; Jackson, 2002 or Sýkora, 2003).

From the point of view of urbanism, unused sites might be understood as a restriction of disposable sources in community with a direct bond to the public budget. Reuse of such abandoned sites improves the quality of life of local population by means of reduction of criminality and occurrence of socially pathological phenomena, improves local environment, increases prices of the land, increases perceived value of properties in neighbourhoods and attracts entrepreneurs (Hollander et al., 2010 or Turečková et al., 2017). Interventions towards brownfield regeneration have to also respect different location of brownfields in different parts of communities, in so call concentric zones (Park \& Burgess, 1925). There is an agreement in the literature that brownfields represent barriers in the contemporary structure of cities that limit urban development (Raco \& Henderson, 2006). Based on the zonal model of cities, it can be assumed that in central - the most attractive parts of cities brownfield regeneration will be directed towards support of small entrepreneurship and housing. This hypothesis is in line with contemporary reurbanization tendencies (Buzar et al., 2007 or Kebza 2018).

Brownfields located in the proximity of the city centres that were during the dynamic development of cities incorporated into them, haven considerably variable use, for example for medium-sized entrepreneurs or as buildings where civic amenities are located (Krzyszt- 
ofik et al., 2012). Brownfields in the margins of cities are suitable for large industrial sites and warehouses. In cases when preserving of brownfields in relatively original form is not desirable or possible (and no other suitable, effective alternative exists), a demolition of brownfield is necessary which is followed by decontamination of the site. New empty greenfield without particular use as the final product of brownfield regeneration is also possible (Johnson, Glover \& Stewart, 2009 or De Sousa, 2000).

Regarding the potential for successful brownfield regeneration, several studies on this topic can be identified trying to explore the general characteristics that determine abandoned areas to be suitable for regeneration. For example, Frantal et al. (2015) in their study claims that a higher rate of brownfields regenerations positively correlates with their occurrence in densely populated and built-up areas, i.e. we assume that a more successful and faster brownfields regeneration process should take place within more populated municipalities. Lange \& McNeil (2004) found that the regeneration of brownfields that are located near airports, near the city centres or rail stations is developing faster.

Martinat et al. (2018) warn that brownfield regeneration is closely interconnected with their perception by future users of particular sites and found out that the perception of regeneration significantly differs according to gender. Navratil et al. (2018) in their study documented that heritage preservation of sites is one of the factors of key importance when planning the regeneration project. In the study of Longo and Campbell (2007), successful regeneration is correlated with the prosperous region, i.e. those regions that are successfully developing and it is assumed that this includes positive impact on brownfield regeneration. Similar logic has been utilized also by other authors who argue that in regions where a higher potential of local development is measured, a higher probability exists that local brownfields will be more successfully regenerated. (Pizzol et at., 2016; Bartke et al., 2016 and Limasset et al., 2018). The specifics of brownfield regeneration in the post-communist space are widely discussed by Osman et al. (2015). Among other key aspects of brownfield regeneration belong existence of strong potential markets, long-term vision, strong branding, strong partnerships, integrated development, and getting infrastructure into place (Dixon et al., 2011).

The aforementioned brownfield regeneration factors can also be easily linked to the existence of short-term and long-term business cycles. There is no doubt that in times of economic expansion there is a significant recovery of abandoned and neglected areas, while in times of recession, economic restructuring and disruptions, the number of brownfields is increasing (Rink et al., 2012 or Dixon, 2006). The process of successful brownfield regeneration can also benefit from the effects of the concentration of sectoral economic activities in the given area (Turečková, 2015). On the contrary, contamination and environmental burden of brownfields is a major problem for brownfield regeneration (Hartley et al., 2012 or Doick, 2009).

The process of brownfield regeneration can be positively influenced through both active and passive activities of public institutions. Within the framework of undesirable burdens and barriers to brownfield regeneration, subsidy programs for financial support (McCarthy, 2002 or Bartke \& Scharze, 2015) can be offered as part of economic policy at central and local levels, and some of them can be used in the public sector (Schädler et al., 2011). Raising awareness about the issue of brownfields by main of their inclusion in public databases might be also mentioned (Otsukaan, Timothy \& Hirokazu, 2013). 


\section{METHODOLOGY AND DATA}

The methods of data analysis accommodated reflect the aim of our research and the availability of data. The starting point of our considerations about this research was publicly available data on brownfields in the Czech Republic that were included in the public database of the state-funded company the CzechInvest in 2018 (the company subordinated to the Ministry of Industry and Trade of the Czech Republic). Our set of non-regenerated brownfields included 460 abandoned sites with which 5 characteristics were analysed due to the characteristics of the data. These were assumed to be key characteristics for brownfield regeneration: (1) the size of particular brownfield (in hectares), (2) ownership of brownfield, (3) contamination of the site, (4) previous use. These four characteristics were supplemented by (5) the distance of individual brownfield to the municipality of extended powers (so-called small district) where the given area administratively belongs (in $\mathrm{km}$ ). This characteristic was measured manually. It needs to be mentioned that for the brownfields to be listed in the CzechInvest database, the owners need to give their consent. Thus, our set contains approximately 5\% of known brownfields in the Czech Republic. However, there is no doubt that the generally used number of 12,000 abandoned sites is underestimated. General information on the analysed set of non-regenerated brownfields is provided in Table 1.

Correspondence analysis of data was employed to analyse the brownfield data (460 entries in total). This analysis represents a popular graphic technique used to analyse relationships between categories of one or more variables in contingency tables. By using correspondence analysis, it is possible to describe associations of nominal or ordinal variables and to obtain a graphical representation of connections in multidimensional environ.

Rencher (2002) emphasizes that the basis for the creation of the subjective (correspondent) map are so-called latent variables. The positions of the points in the subjective map directly express the associations, the distances between the points (or, in other words, the distance of the row and column profiles) can be transferred to a two-dimensional Euclidean space in which the points correspond to the individual categories. Hebak et al. (2007) report that correspondence analysis depicts correspondence categories of individual variables and provides a common picture of row and column categories in the same dimensions. Unlike most other multivariate methods, correspondence analysis allows processing of categorized non-metric data as well as non-linear relationships. It represents an analogy of factor analysis, but instead of factors, the influence of individual categories, their mutual similarity or associations with categories of other variables are monitored (Rencher, 2002). Correspondence analysis and factor analysis are therefore rightly perceived as related methods that can identify at first glance hidden structures in data. According to Hebak et al. (2007), correspondence analysis aims to reduce multidimensional vector space of row and column profiles while preserving the maximum information contained in the original data. In the case of our primary research, we have used the so-called multiple correspondence analysis.

In subjective mapping, two-dimensional (plane) or maximum three-dimensional mapping of distances in Euclidean space is most often used. Pearson's chi-square statistics are used more often than the Euclidean distance. This approach was also selected in this case. Near row points indicate rows that have similar profiles across the row, nearby column points indicate columns with similar profiles down over all rows. Row points that are in proximity to column points represent combinations that appear to be expected more fre- 
quently than in an independent model in which row categories are not related to column categories (Meloun et al., 2005).

The scattering of points can be assessed according to the inertia indicator, which corresponds to the weighted average chi-square by the distance of the row (or column) profiles from its diameter (Meloun et al., 2005).

Table 1.

Characteristics of selected brownfields in the Czech Republic

\begin{tabular}{|c|c|c|c|c|c|c|c|c|}
\hline \multirow{2}{*}{$\begin{array}{l}\text { NUTS } 3 \\
\text { Region }\end{array}$} & \multirow{2}{*}{$\begin{array}{l}\text { Number of } \\
\text { brownfields }\end{array}$} & \multicolumn{2}{|c|}{ Size (hectares) } & \multirow{2}{*}{$\begin{array}{l}\text { Owner- } \\
\text { ship } \\
\text { (public) }\end{array}$} & \multirow{2}{*}{$\begin{array}{c}\text { Contami- } \\
\text { nation } \\
\text { (yes) }\end{array}$} & \multirow{2}{*}{ Previous use } & \multicolumn{2}{|c|}{ Distance (km) } \\
\hline & & mean & median & & & & mean & median \\
\hline $\begin{array}{l}\text { Karlovy } \\
\text { Vary }\end{array}$ & 32 & 6.74 & 1.34 & $25 \%$ & $16 \%$ & $\begin{array}{c}4(11) ; 2(7) ; 3(5) ; 6(5) \\
1(4) ; 5(0)\end{array}$ & 2.02 & 1.25 \\
\hline Plzeň & 24 & 4.30 & 1.87 & $29.2 \%$ & $25 \%$ & $\begin{array}{c}4(11) ; 1(7) ; 3(4) ; 2(1) \\
6(1) ; 5(0)\end{array}$ & 1.78 & 0.68 \\
\hline Ustí & 62 & 3.36 & 1.13 & $32.3 \%$ & $44 \%$ & $\begin{array}{c}4(25) ; 2(10) ; 1(9) ; \\
3(9) ; 6(6) ; 5(3)\end{array}$ & 1.90 & 1.2 \\
\hline $\begin{array}{c}\text { South } \\
\text { Bohemian }\end{array}$ & 33 & 3.23 & 0.84 & $15.2 \%$ & $9 \%$ & $\begin{array}{c}1(12) ; 4(10) ; 2(7) ; \\
3(3) ; 6(1) ; 5(0)\end{array}$ & 1.77 & 0.9 \\
\hline Vysočina & 24 & 1.22 & 0.21 & $25 \%$ & $17 \%$ & $\begin{array}{c}1(8) ; 4(7) ; 2(6) ; 3(3) \\
6(0) ; 5(0)\end{array}$ & 4.68 & 0.78 \\
\hline $\begin{array}{c}\text { Central } \\
\text { Bohemian }\end{array}$ & 30 & 25.8 & 1.49 & $16.7 \%$ & $10 \%$ & $\begin{array}{c}4(16) ; 2(7) ; 1(4) ; 3(2) ; \\
5(1) ; 6(0)\end{array}$ & 4.31 & 1.55 \\
\hline Pardubice & 28 & 2.36 & 0.62 & $46.4 \%$ & $32 \%$ & $\begin{array}{c}4(10) ; 1(9) ; 2(5) ; 3(4) \\
6(0) ; 5(0)\end{array}$ & 2.27 & 0.95 \\
\hline $\begin{array}{l}\text { Hradec } \\
\text { Králové }\end{array}$ & 24 & 4.59 & 1.56 & $20.8 \%$ & $29 \%$ & $\begin{array}{c}4(11) ; 2(7) ; 1(2) ; 4(2) ; \\
5(1) ; 6(1)\end{array}$ & 1.34 & 1.55 \\
\hline Liberec & 59 & 3.08 & 1.46 & $29.5 \%$ & $46 \%$ & $\begin{array}{c}4(29) ; 2(15) ; 1(9) \\
3(5) ; 6(1) ; 5(0)\end{array}$ & 1.83 & 1.30 \\
\hline $\begin{array}{l}\text { Moravian- } \\
\text { Silesian }\end{array}$ & 40 & 5.06 & 1.89 & $27.5 \%$ & $17.5 \%$ & $\begin{array}{c}4(16) ; 3(8) ; 1(7) ; 2(7) \\
6(2) ; 5(0)\end{array}$ & 3.10 & 2.05 \\
\hline Olomouc & 36 & 4.56 & 0.55 & $5.7 \%$ & $3 \%$ & $\begin{array}{c}4(14) ; 2(10) ; 1(5) ; \\
3(3) ; 6(3) ; 5(0)\end{array}$ & 3.34 & 1.7 \\
\hline Zlin & 15 & 1.17 & 0.66 & $6.7 \%$ & $0 \%$ & $\begin{array}{c}4(8) ; 1(4) ; 2(2) ; 3(1) ; \\
6(0) ; 5(0)\end{array}$ & 1.46 & 1.1 \\
\hline $\begin{array}{c}\text { South } \\
\text { Moravian }\end{array}$ & 52 & 3.57 & 1.35 & $26.9 \%$ & $12 \%$ & $\begin{array}{c}4(17) ; 1(13) ; 2(11) ; \\
3(6) ; 6(4) ; 5(1)\end{array}$ & 1.88 & 1.01 \\
\hline Prague & 1 & 0.98 & 0.98 & $0 \%$ & $0 \%$ & $4(1)$ & 11.6 & 11.6 \\
\hline \multirow{2}{*}{ Total } & \multirow{2}{*}{460} & mean & span & share in $\%$ & $\begin{array}{c}\text { share on } \\
\text { all }\end{array}$ & most often & mean & span \\
\hline & & 5.06 & $\begin{array}{l}0.0234 \\
-646\end{array}$ & $25 \%$ & $23 \%$ & $\begin{array}{c}\text { industrial brownfields } \\
\text { (188) }\end{array}$ & 2.40 & $\begin{array}{c}0.04- \\
86.5\end{array}$ \\
\hline
\end{tabular}

Source: CzechInvest, 2018; own survey.

Note: in previous use: (1) agricultural brownfields, (2) brownfields after civic amenities, (3) military brownfields, (4) industrial brownfields, (5) post-mining brownfields and (6) other brownfields.

The singular value and the inertia correspond to the eigenvalue in the principal component analysis. It represents the measure of variability between profiles explained by a given dimension of solution or a given category. According to this step, we determined the number of dimensions required. Profile differences, measured by chi-square statistics, are reflected in the graph as the distance between items of the same variable. The spacing between items of different variables are images of standardized residues at the intersection of items. Meloun et al. (2005) measure besides the object comparability also the completeness 
of data matrix. The solution is based on a matrix of standardized residues, which can be created using one of the standardization methods.

The selection of normalization method depends on the preferences of the researcher as well as the assessment of the degree of variability achieved. When preferring relationships between row categories, the analysis of row profiles is used, while the preference of column categories is based on the analysis of column profiles.

The SPSS Statistics 15.0.1 for Windows software was used to process the data, which represents a modern system for describing and visualizing data relationships. The advantage of the software in data processing is the existence of so-called codebook, which contains information about the data matrix (names and descriptions of variables, descriptions of values, missing values) and which makes the subsequent statistical analyses easier for the user.

\section{RESULTS}

The data file was divided into two dimensions (areas) using correspondence analysis (see Figure 1). The picture itself shows how the resulting data was dimensionally arranged in the cross-section. How do we read the findings? The first dimension in our case consists of three categories of influence of selected variables for potential brownfield regeneration. These are size, ownership and contamination. This is illustrated in Table 2, where Eigenvalues are greater than 1 and thus have a significant impact on the data. In the second dimension and from the regeneration point of view, the category of influence of selected variables is less significant (it is the previous use of brownfields and distance from the centre of the municipality).

Table 2.

\section{Categorization of influence of selected variables for potential regeneration (Correlations Transformed Variables).}

\begin{tabular}{|l|c|c|c|c|c|}
\hline \multicolumn{1}{|c|}{ Variable } & Size & Ownership & Contamination & Previous use & Distance \\
\hline Area & 1.000 & 0.068 & 0.168 & 0.162 & 0.133 \\
\hline Ownership & 0.068 & 1.000 & 0.092 & 0.483 & 0.054 \\
\hline Contamination & 0.168 & 0.092 & 1.000 & 0.020 & -0.020 \\
\hline Previously & 0.162 & 0.483 & 0.020 & 1.000 & 0.161 \\
\hline Distance & 0.133 & 0.054 & -0.020 & 0.161 & 1.000 \\
\hline Dimension & 1 & 2 & 3 & 4 & 5 \\
\hline Eigenvalue & 1.616 & 1.096 & 1.017 & 0.781 & 0.491 \\
\hline
\end{tabular}

The rate of variability in both dimensions reached an average of $30 \%$, which can be considered a satisfactory result. In this sense, it should be noted that we tried to identify the hidden structures of the data which would not be possible to conduct employing other methods. In terms of the quality of interpretations, it needs to be mentioned that we are dealing with data when each region (administrative unit) in the Czech Republic has a different number of brownfields, and therefore the categories of impact on possible brownfield regeneration may vary from our findings. 


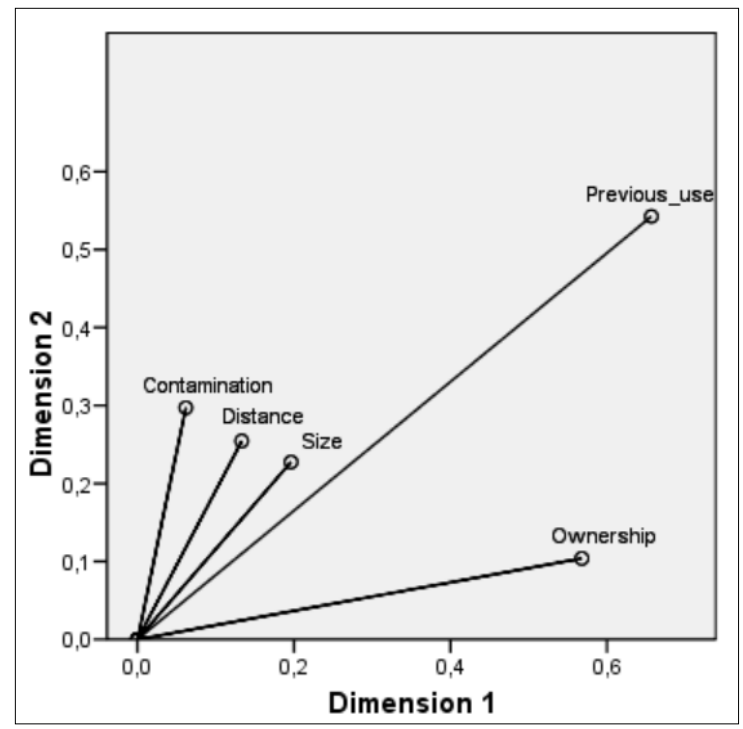

Fig. 1. Principal normalization of variables (discrimination measures).

(Source: own survey, 2019 (SPSS 15.0.1)).

\section{DISCUSSION AND CONCLUSIONS}

Our knowledge of the characteristics and features of brownfields is a basic prerequisite for their possible and appropriate regeneration. When we reveal the factors, features or categories of influence that are common to a given set of abandoned sites, the accommodation of public policy instruments can be more targeted in this direction. In our case, three categories of influence of selected variables in terms of size, ownership and contamination of brownfields were analysed by means of the technique of correspondence analysis. The factors of previous utilization and distance from the municipality centre are not so crucial in the first phase of the decision on potential brownfield regeneration.

If the results of correspondence analysis to partial characteristics of the surveyed brownfields are correlated, then in terms of the size of the abandoned areas an area around 1.14 hectares (average of the median of all regions) may be considered as optimal, while in terms of the ownership it should be privately owned brownfield $(70 \%)^{2}$ that is free of contamination $(77 \%)$. The public sector, which decides to reflect these findings in order to minimize the number of brownfields in its territory, might consider the creation of financial and non-financial instruments that will be more likely targeted on small-sized brownfields owned by private entities, offering them support for remediation of contaminations to support their regeneration. These conclusions and recommendations, based on the analysed brownfield data, are following specifics of brownfields located in the Czech Republic. On the other hand, the methodological and interpretative transferability of the above-described research procedure to other relevant sets of brownfields is generally possible.

\footnotetext{
${ }^{2}$ There are other $5 \%$ of brownfields in public private ownership.
} 
To sum up, in the context of the existence of brownfields it seems a priority to find their new, beneficial use. If we accept this logic, individual brownfields must be considered to have the potential for further development. Together with their regeneration, the growth of economic and social activities and the increase of the attractiveness of the territory for all stakeholders is expected. On the other hand, leaving abandoned sites without trying to find alternative uses prevents further development of built-up areas, adversely affects the environment and society, impedes economic growth and has an overall adverse impact on the entire wider administrative region.

\section{ACKNOWLEDGEMENT}

This paper (research) was supported by the project SGS/20/2019 "Brownfields in urban and rural space: geographic, economic, business and public administrative contexts and their importance for regional development (BURAN 2)”.

\section{R E F E R E N C ES}

Bartke, B. \& Schwarze, R. (2015) No perfect tools: Trade-offs of sustainability principles and user requirements in designing support tools for land-use decisions between greenfields and brownfields. Journal of Environmental Management, 153, 11-24.

Bartke, S., Martinat, S., Klusacek, P., Pizzol, L., Alexandrescu, F., Frantál, B., Critto, A. \& Zabeo, A. (2016) Targeted selection of brownfields from portfolios for sustainable regeneration: User experiences from five cases testing the Timbre Brownfield Prioritization Tool. Journal of Environmental Management, 184, 94-107.

Buzar, S., Ogden, P., Hall, R., Haase, A., Kabisch, S. \& Steinfiihrer, A. (2007) Splintering urban populations: emergent landscapes of reurbanisation in four European cities. Urban Studies, 44 (4), 651-677.

CZECHINVEST (2008). Národní strategie regenerace brownfieldů. Available from: http://www.cityinvestczech.cz/data/files/strategie-regenerace-vlada-1079.pdf [Accessed February 2018].

De Sousa, C. A. (2000) Brownfield redevelopment versus greenfield development: A private sector perspective on the costs a risks associated with brownfield redevelopment in the Greater Toronto Area. Journal of Environmental Planning a Management, 43 (6), 831-853.

Dennison, S. M. (1998) Brownfields Redevelopment, Rockville: Government Institutes.

Dixon, T. (2006) Integrating sustainability into brownfield regeneration: Rhetoric or reality?-An analysis of the UK development industry. Journal of Property Research, 23 (3), 237-267.

Dixon, T., Otsuka, N. \& Abe, H. (2011) Critical success factors in urban brownfield regeneration: an analysis of 'hardcore'sites in Manchester and Osaka during the economic recession (2009-10). Environment and Planning A, 43 (4), 961-980.

Doick, K. J. (2009) Understanding success in the context of brownfield greening projects: The requirement for outcome evaluation in urban greenspace success assessment. Urban Forestry \& Urban Greening, 8 (3), 163-178.

Frantal, B., Greer-Wootten, B., Klusacek, P., Krejci, T., Kunc, J. \& Martinat, S. (2015) Exploring spatial patterns of urban brownfields regeneration: The case of Brno, Czech Republic. Cities, 44, $9-18$.

Hartley, W., Dickinson, N. M., Riby, P. \& Shutes, B. (2012) Sustainable ecological restoration of brownfield sites through engineering or managed natural attenuation? A case study from Northwest England. Ecological Engineering, 40, 70-79. 
Hebák, P., Hustopecký, J., Pecáková, I., Průša, M., Řezanková, H., Svobodová, A. \& Vlach, P. (2007) Vicerozmèrné statistické metody (3). Praha: Informatorium.

Hollander, J. B., Kirkwood, N. \& Gold, J. L. (2010) Principles of brownfield regeneration: clean-up, design, a reuse of derelict land, Washington: Isla Press.

Jackson, J. (2002) Urban Sprawl. Urbanismus a území rozvoj, 5 (6), 21-28.

Johnson, A. J., Glover, T. D. \& Steward, W. (2009) One person's trash in another person's treasure: The public place-making of "Mount Trashmore". Journal of Park a Recreation Administration, 27 (1), 85-103.

Kebza, M. (2018). The development of peripheral areas: The case of West Pomeranian Voivodeship, Poland. Moravian Geographical Reports, 26(1), 69-81.

Krysztofik, R., Runge, J. \& Kantor-Pietraga, I. (2012) Paths of environmental a economic reclamation: the case of post-mining brownfields. Polish Journal of Environmental Studies, 21 (1), 219223.

Lange, D. A., \& McNeil, S. (2004) Brownfield development: Tools for stewardship. Journal of Urban Planning and development, 130 (2), 109-116.

Limasset, E., Pizzol, L., Merly, C., Gatchett, A. M., Le Guern, C., Martinat, S., Klusacek, P. \& Bartke, S. (2018) Points of attention in designing tools for regional brownfield prioritization. Science of The Total Environment, 622, 997-1008.

Longo, A. \& Campbell, D. (2007) What are the determinants of brownfields regeneration? An analysis of brownfields in England. In Proceedings of the conference on the science and education of land use: A transatlantic, multidisciplinary and comparative approach, Washington DC.

Martinat, S., Navratil, J., Hollander, J. B., Trojan, J., Klapka, P., Klusacek, P. \& Kalok, D. (2018) Rereuse of regenerated brownfields: Lessons from an Eastern European post-industrial city. Journal of Cleaner Production 2018, 188, 536-545.

McCarthy, L. (2002) The brownfield dual land-use policy challenge: reducing barriers to private redevelopment while connecting reuse to broader community goals. Land and Use Policy, 19 (4), 287-296.

Meloun, M., Militký, J. \& Hill, M. (2005) Počítačová analýza vícerozměrných dat v př́kladech. Praha: Academia.

Navratil, J., Krejci, T., Martinat, S., Pasqualetti, M. J., Klusacek, P., Frantal, B. \& Tochackova, K. (2018). Brownfields do not "only live twice": The possibilities for heritage preservation and the enlargement of leisure time activities in Brno, the Czech Republic. Cities, 74, 52-63.

Oliver, J. E. (2001) Democracy in Suburbia, Princenton: Princenton Uversity Press.

Osman, R., Frantal, B., Klusacek, P., Kunc, J. \& Martinat, S. (2015) Factors affecting brownfield regeneration in post-socialist space: The case of the Czech Republic. Land Use Policy, 48, 309316.

Pakšiová, R. (2016) Reporting of non-financial information on companies in the context of sustainable development in Slovakia. In: Účetnictví a auditing v procesu světové harmonizace. Mezinárodni vědecká konference. Praha: Vysoká škola ekonomická v Praze, Nakladatelství Oeconomica, 153-160.

Park, R. E. \& Burgess, E. W. (1925) The City. Chicago: University of Chicago.

Pizzol, L., Zabeo, A., Klusacek, P., Giubilato, E., Critto, A., Frantal, B., Martinat, S, Kunc, J., Osman, R. \& Bartke, S. (2016) Timbre Brownfield Prioritization Tool to support effective brownfield regeneration. Journal of Environmental Management, 166, 178-192.

Putman, R. (2001) Bowling Alone. The Collapse and Revival of American Community. New York: Simon and Schuster.

Raco, M. \& Henderson, S. (2006) Sustainable urban planning and the brownfield development process in the United Kingdom: Lessons from the Thames Gateway. Local Environment, 11 (5), 499-513.

Rencher, A. (2002) Methods of Multivariate Analysis. New York: Wiley. 
Rink, D., Haase, A., Grossmann, K., Couch, C. \& Cocks, M. (2012) From long-term shrinkage to regrowth? The urban development trajectories of Liverpool and Leipzig. Built Environment, 38 (2), 162-178.

Schädler, S. et al. (2011) Designing sustainable and economically attractive brownfield revitalization options using an integrated assessment model. Journal of Environmental Management, 92 (3), 827-837.

Stober, D., Brkanić, I., \& Lončar, L. (2018). The preferences of residents and tourists for culturaland architectural heritage in a rural landscape: The case of Zlatna Greda, Croatia. Moravian Geographical Reports, 26(4), 285-297.

Sýkora, L. (2003) Suburbanizace a jeji společenské důsledky. Praha, Sociologický ústav AV ČR.

Turečková, K. \& Chmielová, P. (2019) Regenerace brownfieldů v odvětví kultury v České republice. In: XXII. mezinárodni kolokvium o regionálních vědách. Brno: MU ESF Brno, s. 657-664. ISBN 978-80-210-9268-6

Turečková, K. \& Nevima, J. (2018) Perceiving the impact of brownfields on the real estate prices: a case study from four locations in the Czech Republic. Geographia Technica, 13 (2), 138-151.

Turečková, K. (2015) Sectoral industrial agglomeration and network externalities: concept of ICT sector. In: Proceedings of 5th International Conference on Applied Social Science. USA: IERI, $50-55$.

Turečková, K., Martinát, S., Škrabal, J., Chmielová, P. \& Nevima, J. (2017) How local population perceive impact of brownfields on the residential property values: some remarks from postindustrial areas in the Czech Republic. Geographia Technica, 12(2), 150-164.

Turečková, K., Nevima, J., Škrabal, J. \& Martinát, S. (2018) Uncovering patterns of location of brownfields to facilitate their regeneration: Some remarks from the Czech Republic. Sustainability, 10 (6), 224-234.

Vráblík, P. et al. (2009) Metodika revitalizace území pro hospodářský, sociální a environmentální rozvoj v postižených regionech. Available from: http://fzp.ujep.cz/projekty/wd-44-071/dokumenty/dc03/DC003_Metodika_revitalizace_uzemi.pdf [Accessed February]. 